\title{
Nano Pathology of Corona Virus it can be Curtailed
}

\author{
Shahid Hussain Sheikh* \\ Chairman: NIDS Treatment \& Research Center Trust ${ }^{\circledR}$, Pakistan
}

Submission: April 4, 2020; Published: July 24, 2020

*Corresponding author: Shahid Hussain Sheikh, Chairman: NIDS Treatment \& Research Center Trust ${ }^{\circledR}$, Pakistan

Keywords: Nano Pathology; Corona Virus; Human; Proliferation; Nucleopathy; Genome; Pathophysiology; Alpha protein; Antihistamine; Immunity; Dengue; Beta Protein

\section{Opinion}

HISTORICALLY, many epidemics prevailed over the period leaving a great devastation and human catastrophes. But yet left the man thinking to create something to defy it.

Having lost so many human lives, we must try to understand its modes aparande and best prepare our fool proof strategy to defy it and save the human life. AFM (Atomic Force Microscopy) has revealed by magnifying 1 billion times the genomic level proliferation processes of a typical virus. That help us understand where to intervene.

Thanks to Alex Malkin, Alex McPhearson \& Marco Plomp [1] they have opened the door for us to look at the detailed nano pathology of a virus. Just like they have studied the neuroinvasive virus in such a detail, now we can find the link to the 48 diseases to the Nucleopathy [2], that gives rise to human diseases induced by the neuroinvasive viruses.

CMV \& HSV viral DNA shedding its Alpha messenger RNA and becoming an Alpha protein and Beta messenger RNA becoming Beta Protein to re-attaching to its genome to proliferate also can be stopped by the overwhelming power of DNA-THC [3]. As it demonstrates for CMV \& HSV. Dengue was also an epidemic that had claimed thousands of human lives. But understanding its pathophysiology, directed us, where and when to interfere to win the war against it.

1298 patients successfully treated with zero mortality [4]. Corona 19 also has a definite pathophysiology that needs the closest watch and we need to find and master the strategy to successfully intervene in timely fashion to win the war.
Every virus once enters into a victim it must go through some basic survival modes before it begins to proliferate. That is the best time to capture it and have intrusion in its survival prior to its proliferation. Antihistamine is the greatest weapon known so far in the medical field all across the world. Virus is a virus is a virus. No virus has developed the immunity to antihistamine yet, prophylactically increasing serum level antihistamine can be a best safeguard against this devastating virus. In reference to corona virus The advance level symptoms can be managed accordingly, i.e, surface area of alveoli of the lungs are water filled, Lasix should be used to evacuate the water through urine along with Ventolin must be given to facilitate the breathing. Therefore, a complete fool proof strategy should be developed by classifying the patient into the following categories.

a) Exposed to convid19

b) Intermediary Exposed with early symptoms

c) Advance level, high priority

All body fluids and electrolytes should be continuously checked of course with vitals..

\section{References}

1. Plomp M, Marcia K, McPherson A, Malkin A (2002) Atomic Force Microscopy. AJP160(6).

2. (2014) IOSR Journal of Dental and Medical Sciences 13(3).

3. Biopsychiatry.com. "How THC Affects the Brain.

4. (2013) IOSR Journal of Dental and Medical Sciences (IOSR-JDMS), pp. $01-100$. 

(C) (i) This work is licensed under Creative

DOI: $10.19080 / G J I D D .2020 .06 .555697$

\section{Your next submission with Juniper Publishers} will reach you the below assets

- Quality Editorial service

- Swift Peer Review

- Reprints availability

- E-prints Service

- Manuscript Podcast for convenient understanding

- Global attainment for your research

- Manuscript accessibility in different formats ( Pdf, E-pub, Full Text, Audio)

- Unceasing customer service

Track the below URL for one-step submission https://juniperpublishers.com/online-submission.php 